\title{
Writing Poster at Higher Education: Victor Schwab Theory Analysis
}

\author{
Mega Febriani Sya ${ }^{1}$, Fachri Helmanto ${ }^{2}$ \\ ${ }^{1,2}$ Universitas Djuanda \\ e-mail: ${ }^{1}$ megafebrianisya@ unida.ac.id, ${ }^{2}$ fachri.helmanto@unida.ac.id

\begin{tabular}{ccc}
\hline Diterima & Direvisi & Disetujui \\
$26-01-2020$ & $19-02-2020$ & $25-02-2020$ \\
\hline
\end{tabular}

\begin{abstract}
The management changing is started by an election of a new chairman. Supporting academic of the students, English lecturer assigns a project of poster creation of election using English. This research is to find what extent the poster is delivered to its audience. This study is mix method research with an analytical descriptive as the method. Quantitative and qualitative data are gathered through documents. The data are 5 English posters of Students' election candidates. All of the posters are analyzed based on 5 criteria of Schwab's good writing poster theory. Content analysis is used to validate the data findings. The study reveals all the 5 posters don't meet the criteria. However, all of them gives similarity in showing advantage criterion. Next research should assess into a single poster to give a brief explanation of making a good poster.
\end{abstract}

\section{Keywords: Writing Poster, Schwab Writing Theory, Higher Education}

\begin{abstract}
Abstrak - Perubahan manajemen dimulai dengan pemilihan ketua baru. Mendukung akademik para siswa, dosen Bahasa Inggris memberikan proyek pembuatan poster pemilihan menggunakan Bahasa Inggris. Penelitian ini adalah untuk mengetahui sejauh mana poster disampaikan kepada audiensnya. Penelitian ini adalah penelitian metode campuran dengan metode deskriptif analitis. Data kuantitatif dan kualitatif dikumpulkan melalui dokumen. Data adalah 5 poster bahasa Inggris dari kandidat pemilihan Siswa. Semua poster dianalisis berdasarkan 5 kriteria teori poster tulisan Schwab yang bagus. Analisis konten digunakan untuk memvalidasi temuan data. Studi ini mengungkapkan semua 5 poster tidak memenuhi kriteria. Namun, semuanya memberikan kesamaan dalam menunjukkan kriteria keunggulan. Penelitian selanjutnya harus menilai ke dalam satu poster untuk memberikan penjelasan singkat tentang membuat poster yang baik.
\end{abstract}

Kata Kunci: Poster Menulis, Teori Penulisan Schwab, Pendidikan Tinggi

\section{INTRODUCTION}

Higher education is closely like a real society from an ideal perspective. Students of higher education have an organization which runs for collecting and running the students' aspiration. The organization is annually changing management. The management changing is started by an election of a new chairman

The election serves at least two candidates consisted of two persons for the president and the vice president. Every candidate has their team for succession. The team has to promote the candidates to all students giving profitable information in order to get their vote.

Promoting the candidates at Djuanda University has many methods (talk show, debate, speech, poster, leaflet, and etc.). The methods' deliveries are using Indonesian. Supporting academic of students, English lecturer assigns a project of poster creation of election using English. Using English as promotion language delivery has a new perspective as the students are mostly accustomed to Sundanese and Indonesian.
Posters are made for the public (Kusrianto, 2007; Yunregiarsih et al., 2014) and used as a pictorial aid to show any specific pieces of evidence in a concise way (Feketer et al., 2003; Jackson \& Sheldon, 2000) in an academic environment (Zerin \& Khan, 2013). The poster has several words and images in common, but they have meaningful messages (Shelledy, 2004). Writing a poster for higher education students must acknowledge their intentions. however, the students' cellphone is the most seeing of their time in a day.

The students have limited time to read as the time would be valuable for other activities such as moving to the next classes and/or doing the organization's activities. The students would spare their time only if the poster gives an interesting layout and/or a headline (Shaw, 2012). The poster layout is a combination of the colour and the symbols used (Konstant, 2011). The symbols are images related to the purpose of the poster (Allan et al., 2008; Gosling, 2012) (i.e. a close-up photo of the president and vice president candidates).

As described above, the poster created by the students of non-native English is attracting to 
conduct research. However, analyzing posters have been done before that comes up with its results. Most of them are individual analysis of movie poster (Akbar PS \& Patria, 2016; Juliantari, 2014; Werang, Basilius, 2018). The others are poster creation analysis of famous artists (Ramalia et al., 2016; Rukiah, 2016).

Its explanation drives a question whether or not the poster aligned with the criteria of good writing. To distinguish this article to previous research is this study using Victor Schwab Poster Analysis. Therefore, this research is to find what extent the poster is delivered to its audience.

\section{RESEARCH METHOD}

This study is a mix method research with an analytical descriptive (Auerbach \& Silverstein, 2003; Kington et al., 2011; Stake, 2010; Vaismoradi et al., 2013). Quantitative and qualitative data are gathered through documents. This method is dependent to the instrument for measurement and observation to describe some phenomenon of interest (Bhattacherjee, 2012).

Descriptive research describes the event in greater or less depth as needed which focus on various elements of different research techniques and engage in quantitative statistics to organize information in meaningful ways.

The data are 5 English posters project of students' election candidates at Djuanda University. The data are limited to English poster project only. The posters are captured using a cellphone. All of the posters are analyzed based on 5 criteria of Schwab's good writing poster theory. Content analysis is used to validate the data findings.

Schwab theory in writing a good poster defines a good poster has 5 criteria to be met (Schwab, 2016). The 5 criteria are getting attention, showing people an advantage, proving the evidence, persuading people (Lakhani, 2011; Vitale, 2010), and asking for action. Those criteria apply as an instrument to assess the 5 posters are categorized as good posters.

\section{FINDINGS AND RESULTS}

All the 5 posters don't meet the Schwab theory of good poster writing. The finding is supported in the analysis of the criteria as follows.

Table 1 Poster Criteria Analysis

\begin{tabular}{|c|c|c|c|c|c|}
\hline Poster ID & P1 & P2 & P3 & P4 & P5 \\
\hline Getting & $\checkmark$ & & $\checkmark$ & & \\
\hline
\end{tabular}

\begin{tabular}{|c|c|c|c|c|c|}
\hline attention & & & & & \\
\hline $\begin{array}{l}\text { Showing } \\
\text { advantage }\end{array}$ & $\checkmark$ & $\checkmark$ & $\checkmark$ & $\checkmark$ & $\checkmark$ \\
\hline Proving & & & & & \\
\hline Persuading & & & & & \\
\hline $\begin{array}{l}\text { Asking for } \\
\text { action }\end{array}$ & $\checkmark$ & & $\checkmark$ & & \\
\hline
\end{tabular}

A good writing poster originally is a part of writing activity. Writing is an activity to communicate someone's thought in symbols way (Tomasello, 2014). The symbols have specific meaning to specific receivers. The writing activity, at least, has 3 elements (writer-channel/medium-reader) (Hayot, 2014).

In academic, writing becomes an indicator of someone's proficiency. Knowing that phenomenon, writing become a must in set of learning process. The learning process of writing conveys the revealing idea, though, knowledge, and experience of someone in a way of clearly, chronologically, expressively, readability and understandably symbols (Bolton, 2010; Ferreti \& Lewis, 2013; Shaw, 2012; Temple, 1993; Vitale, 2010). A good writing has to be meaningful (Eodice et al., 2017) and align with the purposes (Meyer, 2010).

Purposes of writing are commonly categorized as 1) assignment, 2) altruistic, 3) persuasive, 4) informational, 5) self-expressive, and 6) creative (Ferreti \& Lewis, 2013; Ismayani, 2017; Lubis, 2014; Temple, 1993; Wuryantoro et al., 2017).

Assignment purpose means the writing activity is based on the task given by the lecturer (i.e. short story). Altruistic purpose means to amusing the reader, to giving the reader easy understanding of the text. The persuasive purpose means to convince the reader on the topic described.

The informational purpose means to give information. The persuasive purpose seems similar with the informational purpose. To differ both of them, the informational has no intention of getting readers attention to do specific act. Next, the selfexpressive purpose relates to declare about the writers themselves.

Last, the creative purpose aligns with the value and the creativity of the writers in writing to solve the problems, to make clear the idea and the thoughts for the sake of reader readability.

Mass media is separated into two (electronic \& printed) forms (Grossberg et al., 2006; Romli, 2017; Vivian \& Maurin, 1991). The electronic mass media are such as radio, television, film, website, etc. Radio is basically using an audio. Television is using 
a combination of visual and audio. Film is like television but film does not have break.

Next, the printed mass media is a medium of communication in a static way. The printed mass media are such as newspaper, magazine, tabloid, book, brochure, booklet, etc. Newspaper (daily publishing in common), magazine (once a week or twice a month or monthly publishing) consist news. Tabloid is like a newspaper but it is on A3 paper size. Book is known as the core of knowledge of someone. Brochure is a company profile. Booklet in Indonesia known as memorable things of a company.

Posters as part of printed mass media have some characteristics, in which are: 1) delivered in individual and/or in organizational; 2) having a message to disseminate; 3) anonymous receiver; 4) categorized to a massive number of audiences; 5) having indirect feedback.

To be clearer, poster is identified by 1) giving a specific message or an idea, 2) giving wide impression or attention, 3) direct and dynamic, 4) representative images or illustrations, 5) light, concise, and meaningful words used, 6) symbolizing pictograph bringing a specific idea, and 7) simple but eye-sighting.

Poster is a tool of mass media for informing, guiding, and/or announcing something by symbols and images. The symbols are the words concise and meaningful. The symbols are supported by suitable images to help reader easy to understand the message on the poster.

The images on a poster are used to attract reader to read more (Hartanto, 2001). The function of the images is as a hook leading reader to know more the message of the poster. The images can say better than words (Damono, 2018).

As the writing purpose, poster is categorized into a persuasive writing purpose. The persuasive writing needs the writer intending to the reader to do the act.

Poster as a product is categorized into two functions. 1) as a social exposure, this kind of poster is constructed to communicate things for noncommercial for example 'the effect of smoking' poster. 2) as a commercial tool, this poster is built for business strategy in getting new customer of a product.

Recent posters are created based on 3 (three) approaches, which are dogmatic, argumentative, and appeal (Harahap, 2008). Dogmatic approaches in creating poster is proposing a message as the one and only of a truth. Then, argumentative approaches in creating poster is raising the reader to keep asking 'why?'. This approach gives more logical sequences on the presentation. Last, appeal approach in creating is showing off the uniqueness of images, illustrations, or cartoon

Victor O. Schwab gives easy criteria to indicate a good poster. The criteria are explained as follows.

Getting attention includes layout and headlines. Some posters are intended to be reused over time. A composition of layout provides representative images aligned with the poster purposes. See the kind of poster that using the scrapbook idea below.

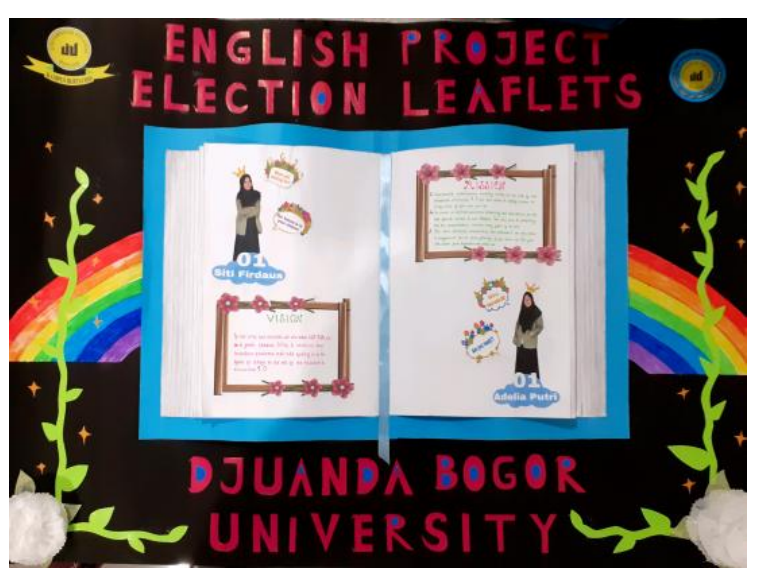

Figure 1. A poster using Scrapbook Idea (Source: English Poster Project 2019)

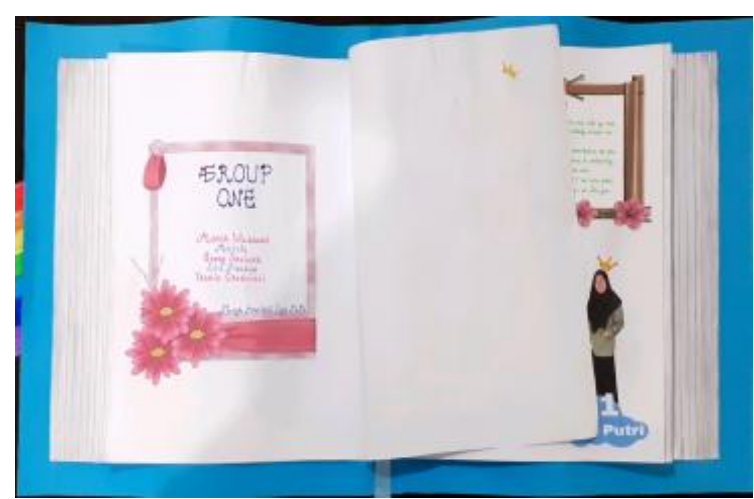

Figure 2. $1^{\text {st }}$ Content Layout: the Creator Profile (Source: English Poster Project 2019)

The poster above is built by putting a book with pages (fig 1). Putting logos also help readers to indicate the organization which be responsible of this poster creation. The layout is centered mode. The error of the layout is putting dark colour logo (on the top right) on black background. Though, the middle (white and blue area) seems like a book with pages. each page consists valuable information. The interesting thing of the poster is the poster are invited reader to flip the pages to find more 
information. The pages of content layout are shown as follows.

On Figure 2, putting identity in a poster is a must since the readers will easily find who is/are responsible on the message given.

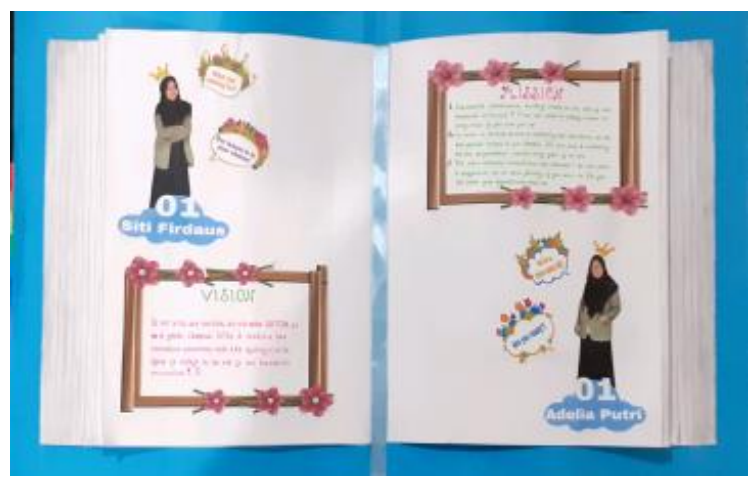

Figure 3. $2^{\text {nd }}$ Content Layout: Give the Advantage (Source: English Poster Project 2019)

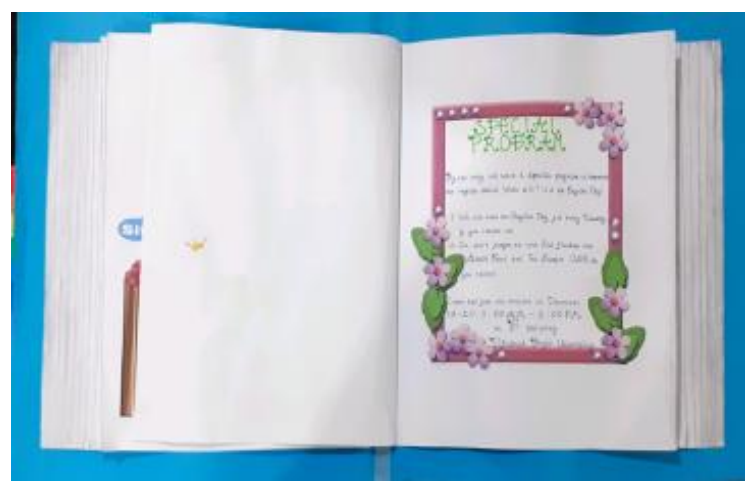

Figure 4. $3^{\text {rd }}$ Content Layout: Give More Advantage (Source: English Poster Project 2019)

Putting advantages (figure 3 and 4) are good idea since it will convince the reader of the content of the message. As the poster is for chairman of the campus's organization. The advantages are talking about the vision and the missions of the candidates.

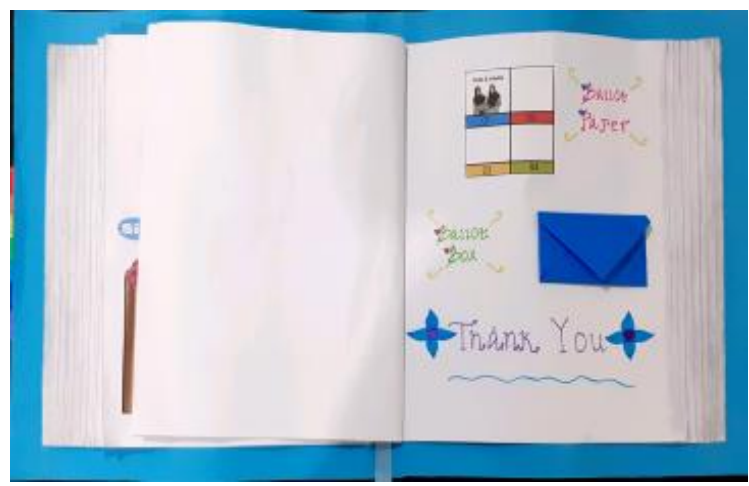

Figure 5. $4^{\text {th }}$ Content Layout: Ask for Action(Source: English Poster Project 2019)

The last part of the scrap-book-poster is guiding the reader to do vote. This part is belonging to ask for action elements.

In addition, the headline roles as a hook to lead the audience to find more the information given. However, there are some rules to make a good headline (Erren \& Bourne, 2007). The first rule is defining the purpose. Headline must align with the purpose. Preparing a poster on this rule is started by questioning 'what do you want others to do?' the second rule is be concise and clear. The third is putting the title that sharp, short, and gripping. The fourth is showing the uniqueness. For example, "Talk Less Do More"

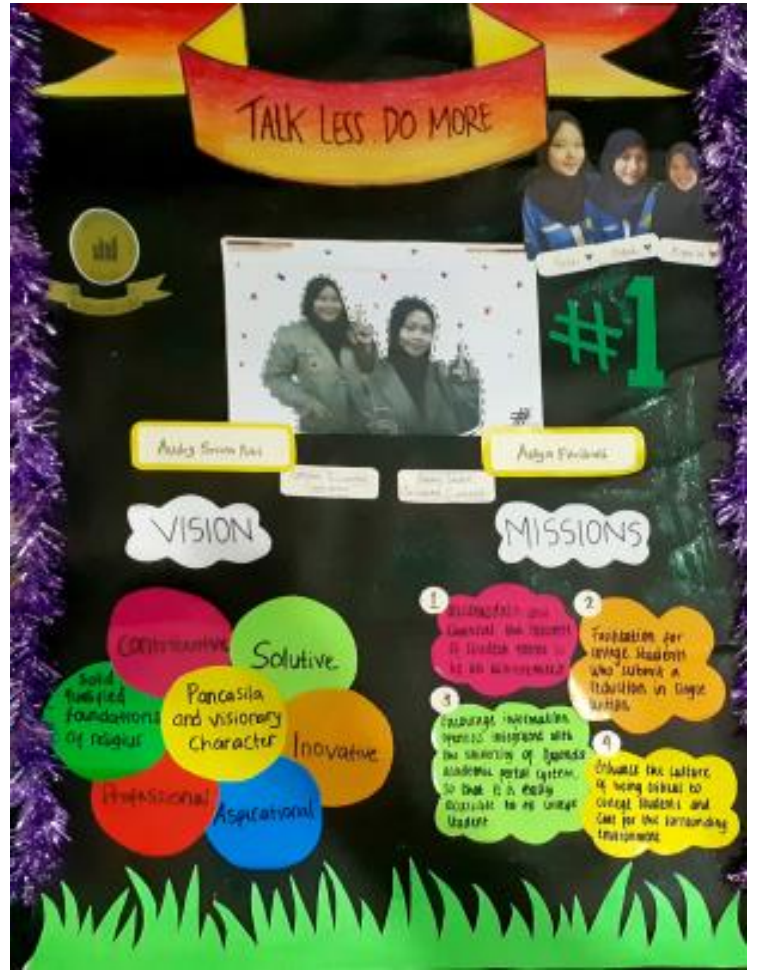

Figure 6 Headline Example: Short, Concise, and Gripping (Source: English Poster Project 2019)

Showing people advantage is mainly about capturing the audience mind. There are two aspects (plus and minus) to get the audience minds. The plus aspect shows in words or images what the audience gain. Contrary, the minus shows in words or images what the audience probably lose in a positive perspective.

Proving the evidence is putting facts and/or review on the main content of the advertisement. Putting more facts will attract more audience to believe in 
the substance of the poster. Also, putting reviews would convince the audience.

Persuading people is giving a reason to the audience that the poster content is profitable. Actually, proving by facts and reviews are enough already to convince the audience. This persuading part would be likely a sum up, reiteration, reminding about the advertisement content using strong close statement.

As presented above (figure 5), asking for action is the key of succession for the promotion on the poster. It can be delivered into three optional ways. First, there is a direct statement, in which this would like to invite the audience to do or what is stated on the poster (i.e. choose us).

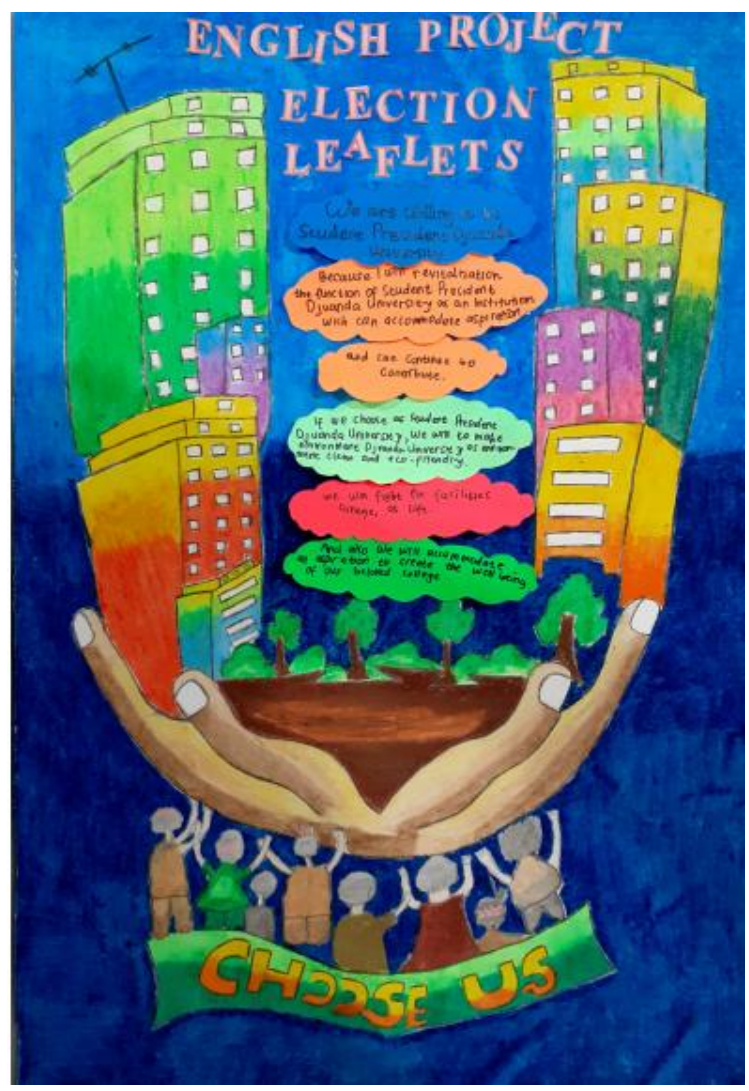

Figure 7 Asking for Action Example (Source: English Poster Project 2019)

Second, it is inviting by highlighting the benefit that the audience probably gained. Last, it is an offer such as trial for premium, the limit of the time or product, and price down such as a discount.

Some errors are found on those 5 posters. all of them are in A2-A3 paper size. However, on the title section, it has 'leaflet' word (see Fig $1 \&$ 7). The leaflet is a handy paper size.

\section{CONCLUSION}

The study reveals all the 5 posters don't meet the criteria. However, all of them gives similarity in showing advantage criterion. the students seem like not following the criteria in making the posters. The errors in grammatical and typo are found easily.

This research is suggesting to disseminate the Schwab theory of good poster writing at the English class. This study is limited to 5 posters and the students are using their own understanding of making advertisement without knowing the 5 criteria of a good poster writing. Furthermore, next research should assess into a single poster to give a brief explanation of making a good poster.

\section{REFERENCES}

Akbar PS, D., \& Patria, A. S. (2016). Analisis Poster Film James Bond Karya Andreanus Gunawan. Jurnal Pendidikan Seni Rupa, 4(02), 360-364.

Allan, C., Bailey, J., \& Pointon, L. (2008). Students' Approaches to Poster Making. Employment Relations Record, 8(2), 15.

Auerbach, C. F., \& Silverstein, L. B. (2003). Qualitative Data. New York University Press.

Bhattacherjee, A. (2012). Social Science Research: Principles, Methods, and Practices. In Pure and Applied Chemistry (Second, Vol. 61, Issue 9). https://doi.org/10.1351/pac198961091657

Bolton, G. (2010). Reflective Practice: Writing and Professional Development. Sage Publications.

Damono, S. D. (2018). Alih Wahana. Gramedia Pustaka Utama.

Eodice, M., Geller, A. E., \& Lerner, N. (2017). The Meaningful Writing Project: Learning, teaching and Writing in Higher Education. University Press of Colorado.

Erren, T. C., \& Bourne, P. E. (2007). Ten Simple Rules for a Good Poster Presentation. PLoS Computational Biology, 3(5).

Feketer, J., Wang, D., Dang, N., Aris, A., \& Plaisant, C. (2003). Interactive Poster: Overlaying graph links on Treemaps. Proceedings of the IEEE Symposium on Information Visualization Conference Compendium (InfoVis 03), 82-83.

Ferreti, R. P., \& Lewis, W. E. (2013). Best Practices in Teaching Argumentative writing. In Best Practice in Writing Instruction (pp. 113-140). 
Gosling, P. J. (2012). Scientist's Guide to Poster Presentations. Springer Science \& Business Media.

Grossberg, L., Wartella, E., Whitney, D. C., \& Wise, J. M. (2006). Mediamaking: Mass Media in a Popular Culture. Sage.

Harahap, R. E. (2008). Analisis Semiotik Pada Poster Hiv / Aids. In Skripsi. http://repository.uinjkt.ac.id/dspace/bitstream/ 123456789/7315/1/RANITA ERLANTI HARAHAP-FDK.pdf

Hartanto, D. D. (2001). Penggunaan Ilustrasi Sebagai Daya Tarik Pada Iklan Media Cetak. Nirmana, 3(1), 40-48. http://puslit2.petra.ac.id/ejournal/index.php/dk v/article/view/16064

Hayot, E. (2014). The Elements of Academic Style: Writing for the Humanities. Columbia University Press.

Ismayani, R. M. (2017). Kreativitas dalam Pembelajaran Literasi Teks Sastra. Semantik, 2(2), 67-86

Jackson, K., \& Sheldon, L. (2000). Demystifying the Academic Aura: Preparing a Poster. Nurse Researcher, 7(3), 70-73.

Juliantari, N. (2014). Semiotic Analysis of "the Conjuring" Movie Poster Advertisement. Humanis, 9(3), 1-7.

Kington, A., Sammons, P., Day, C., \& Regan, E. (2011). Stories and Statistics: Describing a Mixed Methods Study of Effective Classroom Practice. Journal of Mixed Methods Research, 5(2), 103-125.

Konstant, T. (2011). Ten Rules Of Copywriting. Hodder Education.

Kusrianto, A. (2007). Pengantar Desain Komunikasi Visual. ANDI.

Lakhani, D. (2011). Persuasion: The Art of Getting What You Want. John Wiley \& Sons.

Lubis, R. F. (2014). Writing Narrative Text. English Education, 02(01), 61-76.

Meyer, C. (2010). Fast Cycle Time: How to Align Purpose, Strategy, and Structure for. Simon and Schuster.

Ramalia, V., Soedarsoni, D. K., \& Esfandari, D. A. (2016). Makna Poster Di Tanah Kami Nyawa Tak Semahal Tambang (Analisis Semiotika Charles Sanders Peirce Pada Poster Kasus
Pembunuhan Salim Kancil). E-Proceding of Management, 3(3), 3846-3853. https://doi.org/10.4234/jjoffamilysociology.28. 250

Romli, K. (2017). Komunikasi Massa. Gramedia Widiasarana Indonesia.

Rukiah, Y. (2016). Kajian Estetika Poster Tadanori Yokoo-1965. Jurnal Desain, 3(03), 198-212.

Schwab, V. O. (2016). How to Write a Good Advertisement. Pickle Partner Publishing.

Shaw, M. (2012). Copywriting: Successful Writing for Design, Advertising, and Marketing (Second). Laurence King.

Shelledy, D. C. (2004). How to make an effective poster. Respiratory Care, 49(10), 1213-1216. https://doi.org/10.15694/mep.2015.004.0001

Stake, R. E. (2010). Qualitative Research: Studying How Things Work. The Guilford Press.

Temple, C. (1993). The Beginnings of Writing. Allyn and Bacon.

Tomasello, M. (2014). A Natural History of Human Thinking. Harvard University Press.

Vaismoradi, M., Turunen, H., \& Bondas, T. (2013). Content Analysis and Thematic Analysis: Implications for Conducting a Qualitative Descriptive Study. Nursing \& Health Sciences, 15(3), 398-405.

Vitale, J. (2010). Hypnotic Writing: How to Seduce and Persuade Customers with Only Your Words. John \& Wiley.

Vivian, J., \& Maurin, P. (1991). The Media of Mass Communication. Allyn and Bacon.

Werang, Basilius, R. (2018). The Effect Of Workload, Individual Characteristics, and School Climate On Teachers' Emoional Exhaustion In Elementary Schools Of Papua. Cakrawala Pendidikan, 37(2), 457-469. https://doi.org/10.1037/0022-3514.51.6.1173

Wuryantoro, A., Saputro, A. N., \& Waraulia, A. M. (2017). Pembelajaran Menulis Sastra yang Berorientasi pada Pembentukan Karakter Siswa Kelas VIII. Prosiding Seminar Nasional Hasil Penelitian LPPM Universitas PGRI Madiun, 249-253.

Yunregiarsih, L. G., Tarmini, W., \& Mustofa, A. (2014). Pola Sintaksis pada Poster dan Impilkasinya dalam Pembelajaran Bahasa Indonesia di SMP. Jurnal Kata (Bahasa, 
Sastra, Dan Pembelajarannya), 2(3).

Zerin, S., \& Khan, S. A. (2013). Poster-A Visual Stimulus for Active Learning. GSTF International Journal of Law and Social Sciences, 3(1), 129-134. https://doi.org/10.5176/2251-2853_3.1.147 